\title{
Response of Jatropha on a Clay Soil to Different Concentrations of Micronutrients
}

\author{
A. A. Abd El-Kader ${ }^{1}$, M. M. Hussein ${ }^{2}$, A. K. Alva ${ }^{3}$ \\ ${ }^{1}$ Soils and Water Use Department, National Research Center, Cairo, Egypt; ${ }^{2}$ Water Relations and Field Irrigation Department, Na- \\ tional Research Center, Cairo, Egypt; ${ }^{3}$ United States Department of Agriculture-Agricultural Research Service, Vegetable and For- \\ age Research, Prosser, USA. \\ Email: ashok.alva@ars.usda.gov
}

Received August $2^{\text {nd }}, 2012$; revised August $30^{\text {th }}, 2012$; accepted September $5^{\text {th }}, 2012$

\begin{abstract}
In recent years Jatropha curcas L. has emerged as a biofuel crop with potential for its production in marginal land with application of treated sewage water. Since this is a new crop for its profitable cultivation, additional research is needed to develop optimal management programs, including macro and micronutrients applications. A pot experiment was conducted in a Greenhouse at the National Research Center, Dokki, Cairo, Egypt, during 2010 summer to evaluate effects of varying concentrations of iron $(\mathrm{Fe})$, manganese $(\mathrm{Mn})$, and zinc $(\mathrm{Zn})$ in irrigation water $(0,50,100,150,200$ and $250 \mathrm{ppm}$ ) on the growth, biomass production, photosynthetic pigments, and mineral nutrients status in the plants. Increasing concentrations of $\mathrm{Fe}, \mathrm{Mn}$, and $\mathrm{Zn}$ in irrigation water up to $150 \mathrm{ppm}$ increased the biomass weight, photosynthetic pigments, and nutrient uptake by Jatropha plants. Further increase in concentrations of micronutrients showed negative effects on the above response parameters. Therefore, this study demonstrates that Jatropha can be grown under irrigation using waste water containing reasonable concentrations of micronutrients and heavy metals. This property of Jatropha provides some support for potential use of this crop for phytoremediation of metal contaminated soils. However, long term field research is needed to further verify both the above beneficial effects.
\end{abstract}

Keywords: Irrigation; Growth; Jatropha curcas L.; Mineral nutrition; Photosynthetic Pigments; Heavy Metals; Sewage Sludge

\section{Introduction}

Egypt is facing fresh water shortage due to rapidly increasing demands of population growth, which is about 2 million per year. The expansion of agricultural production in the desert area to meet the growing demand for food production has further accelerated the increasing pressure on the available fresh water resources. Therefore, there is an interest in using poor quality water for irrigation. One such source of poor quality irrigation water is treated sewage water, which contains large amount of organic materials and some inorganic elements essential for plant growth. But it also may contain non-essential heavy metals which when present in large amount could be harmful if consumed in excess quantities through food chain [1]. Although the use of treated waste water is restricted for irrigation of food crops, this can be a good source for irrigation of non-food crops.

The concentrations of $\mathrm{Fe}, \mathrm{Mn}$, and $\mathrm{Zn}$ in treated sewage water in different locations in Egypt are in the range of 5100 - 20900, 120 - 476 and $243-1200$ ppm respectively. Excessive availability of micronutrients, including
$\mathrm{Zn}, \mathrm{Fe}, \mathrm{Mn}$ and $\mathrm{Cu}$, in the growing medium can affect normal ionic balance by interfering with the uptake, transport, and osmotic regulation of essential ions. This in turn will disrupt metabolic processes such as transpiration, photosynthesis and enzyme activities related to metabolism. Zinc phytotoxicity also induces oxidative stress by generating free radicals and reactive oxygen species (ROS) [2-4].

Increasing energy consumption worldwide has shifted attention to explore additional sources of energy alternate to fossil fuels. Recently, Jatropha has been investigated mainly as a potential source of oil substitute for diesel. Jatropha can also be used as a green manure, hence can be used as a soil amendment for improving soil properties. The multitude of beneficial uses of this crop [5] is anticipated to result in large scale planting, particularly on somewhat marginal land. This is expected to result in increased employment opportunities both for its production and processing, thus can boost rural economy [6-9]. Substantial expansion in acreage under this crop is necessary to make significant contributions towards lowering the reliance on fossil fuels [10]. Despite growing in- 
terest and advocacy in expanding acreage under Jatropha, very little is known on agronomic management of this crop with respect to optimal management of all inputs to maximize total production and net returns. Jatropha seedlings have demonstrated a high degree of tolerance to $\mathrm{Cu}$ concentrations up to $800 \mathrm{ppm}$ in sand culture [11], and tolerance to $400 \mathrm{ppm}$ lead in vitro embryo culture [12]. However, the effects of elevated concentrations of multiple micronutrients, such as $\mathrm{Zn}, \mathrm{Mn}$ and Fe, on the growth of Jatropha have not been studied. Therefore, the aim of the present study was to investigate the effects of different concentrations of $\mathrm{Zn}, \mathrm{Mn}$ and $\mathrm{Fe}$ on the growth of Jatropha seedlings.

\section{Materials and Methods}

A pot experiment was conducted in a greenhouse during the 2010 summer at the National Research Center (NRC), Dokki, Giza governorate, Egypt. This region is characterized by an arid climate with warm winter and hot summer with average daily temperature ranges from $14^{\circ} \mathrm{C}$ to $31^{\circ} \mathrm{C}$. The long-term average rainfall is about $25.7 \mathrm{~mm} /$ year, and relative humidity from $50 \%$ to $70 \%$ [13]. Soil used in the pot experiment was sampled from $0-15 \mathrm{~cm}$ depth from NRC Experiment Station, Shalkan Kalubia governorate, Egypt. Some physical and chemical properties of the soil used in this study, as described by Cottenie et al. [14] are presented in Table 1. Eighteen pots of $35 \mathrm{~cm}$ in diameter and $50 \mathrm{~cm}$ deep were used. Each pot contained $30 \mathrm{~kg}$ of air dried clay loam soil and received 60, 80, and $60 \mathrm{~g} /$ pot N, P, and K, respectively, using urea, single super phosphate, and muriate of potash. The above N, P, and $\mathrm{K}$ rates were equivalent to 115,154 , and $115 \mathrm{~kg} / \mathrm{ha}$. Full rates of $\mathrm{P}$ and $\mathrm{K}$ were applied at pre-planting. Nitrogen was applied in two equal doses, i.e. pre-planting and 30 days after seedling emergence. Five seeds were sown per pot. Plants were thinned 21 days after emergence to leave two plants / pot. The treatments included six concentrations of three micronutrients $(\mathrm{Mn}, \mathrm{Zn}$, and $\mathrm{Fe}$ ) in irrigation water at either $0,50,100,150,200$, or $250 \mathrm{ppm}$ using $\mathrm{MnSO}_{4} \mathrm{ZnSO}_{4} \cdot 7 \mathrm{H}_{2} \mathrm{O}$ and $\mathrm{FeSO}_{4}$ reagent grade chemicals. The above treatments were applied three times within the two and a half month growing period, i.e. 30,45 and 60 days after seedling emergence. Irrigation was done to replenish the water deficit when the available soil water was depleted to $60 \%$ water holding capacity. The soil water depletion was measured by weighing the pots. A randomized block design was adapted with 3 replications. At end of the two and a half month growing period fully expanded two leaves from the top were sampled for analysis. Plant height, number of green leaves, fresh and dry weights were recorded. The sampled leaves were washed, air-dried, and dried in oven at $70^{\circ} \mathrm{C}$, and ground in a stainless steel mill. Chemical analysis was carried out according to the method described
Table 1. Physical and chemical characteristics ${ }^{1}$ of the soil used in the pot experiment.

\begin{tabular}{|c|c|c|}
\hline \multicolumn{3}{|c|}{ Particle size distribution: } \\
\hline Coarse Sand & $>200 \mu \mathrm{m}$ & 9.70 \\
\hline Fine Sand & $200-20 \mu \mathrm{m}$ & 16.75 \\
\hline Silt & $20-2 \mu \mathrm{m}$ & 35.22 \\
\hline Clay & $<2 \mu \mathrm{m}$ & 38.33 \\
\hline Soil Texture & & Clay loam \\
\hline \multicolumn{3}{|c|}{ Soil Chemical Analysis } \\
\hline $\mathrm{pH}$ & $(1: 2.5)$ & 7.50 \\
\hline $\mathrm{EC}\left(\mathrm{dS} \cdot \mathrm{m}^{-1}\right)$ & $(1: 5)$ & 1.45 \\
\hline $\mathrm{CaCO}_{3}(\%)$ & & 2.65 \\
\hline $\mathrm{CEC}\left(\mathrm{C}\right.$ mole $\left.\cdot \mathrm{kg}^{-1}\right)$ & & 30.56 \\
\hline $\mathrm{OM}$ & $(\%)$ & 1.35 \\
\hline \multicolumn{3}{|c|}{ Soluble Cations (meq/100 g soil) } \\
\hline $\mathrm{Na}^{+}$ & & 1.95 \\
\hline $\mathrm{K}^{+}$ & & 0.36 \\
\hline $\mathrm{Ca}^{2+}$ & & 2.68 \\
\hline $\mathrm{Mg}^{2+}$ & & 1.57 \\
\hline \multicolumn{3}{|c|}{ Soluble Anions (meq/100 g soil) } \\
\hline $\mathrm{HCO}_{3}^{-}$ & & 0.97 \\
\hline $\mathrm{Cl}^{-}$ & & 1.8 \\
\hline $\mathrm{SO}_{4}^{-2}$ & & 3.79 \\
\hline \multicolumn{3}{|c|}{ Available macro-nutrients (\%) } \\
\hline $\mathrm{N}$ & & 0.49 \\
\hline $\mathrm{P}$ & & 0.27 \\
\hline $\mathrm{K}$ & & 0.93 \\
\hline \multicolumn{3}{|c|}{ Available micro-nutrients (ppm) } \\
\hline $\mathrm{Zn}$ & & 3.5 \\
\hline $\mathrm{Fe}$ & & 5.4 \\
\hline $\mathrm{Mn}$ & & 7.8 \\
\hline
\end{tabular}

${ }^{1}$ Cottenie et al. [14]. EC = Electrical conductivity; $\mathrm{CEC}=$ Cation exchange capacity; $\mathrm{OM}=$ Organic matter content.

by Cottenie et al. [14]. Total nitrogen was determined micro Kjeldahl method, and phosphorus was determined calorimetrically at a wave length of $430 \mathrm{~nm}$ using spectrophotometer. Potassium, $\mathrm{Ca}$, and $\mathrm{Na}$ concentrations were determined using Jenway flame photometer. Concentrations of $\mathrm{Mg}, \mathrm{Mn}$, and Fe were measured by using atomic absorption spectrophotometer, IL 157. Chlorophyll $\mathrm{a}, \mathrm{b}$ and carotenoids contents were determined following the procedure described by Saric et al. [15]. The statistical significance of responses were evaluated following the procedure described by Snedecor and Cochran [16].

\section{Results and Discussion}

\subsection{Some Growth Characteristics}

Increased concentrations of $\mathrm{Mn}, \mathrm{Zn}$, and $\mathrm{Fe}$ in irrigation water increased plant height, biomass weight, number of leaves, and leaf area per plant of Jatropha plants (Table 2). The above response parameters peaked at 150 to 200 ppm concentrations of micronutrients. With further increase in concentrations to $250 \mathrm{ppm}$, the above response parameters declined. The results indicate that application of micronutrients was very effective in promoting the growth of Jatropha plants. The above growth promotion 
Table 2. Influence of micronutrients (Mn, Zn, Fe) concentrations in irrigation water on some growth parameters of Jatropha plants, 75 days after emergence (DAE).

\begin{tabular}{cccccc}
\hline $\begin{array}{c}\text { Concentrations } \\
(\mathbf{p p m})\end{array}$ & $\begin{array}{c}\text { Plant height } \\
\mathbf{( c m})\end{array}$ & Leaf number & $\begin{array}{c}\text { Fresh weight } \\
\mathbf{( g m})\end{array}$ & $\begin{array}{c}\text { Dry weight } \\
(\mathbf{g m})\end{array}$ & $\begin{array}{c}\text { Leaf area } \\
\left(\mathbf{c m}^{2}\right)\end{array}$ \\
\hline 0 & 77 & 20 & 56 & 10.2 & 69 \\
50 & 90 & 24 & 67.5 & 12.2 & 87 \\
100 & 110 & 33 & 92.3 & 16.7 & 103 \\
150 & 128 & 41 & 115.0 & 20.8 & 109 \\
200 & 118 & 37 & 105.0 & 19.0 & 98 \\
250 & 112 & 40 & 112.0 & 20.3 & 85 \\
LSD (P $\leq 0.05)$ & 13 & 5 & 15 & 2 & 10 \\
\hline
\end{tabular}

LSD $=$ Least significant difference. The treatment differences in excess of the LSD for the respective parameter indicate significant differences.

effect was due to the role of micronutrients in enhanced $\mathrm{N}$ assimilation. Our results are somewhat contradictory to that of [17], who reported no growth promotion of Jatropha curcas plants over 160 days with increased concentrations ( 1 to $4 \mathrm{mg} / \mathrm{l})$ of $\mathrm{Cu}$ and that of $\mathrm{Zn}$ (1 to 8 $\mathrm{mg} / \mathrm{l})$. The lack of growth promotion in the latter study appears to be due to rather low concentration increments of micro nutrients, unlike that used in our study. Inadequate availabilities of macro- and micro-nutrients to Jatropha curcas L. resulted in visual symptoms of nutritional deficiencies [18]. The impact of nutrient deficiencies on biomass production decreased in the order: $\mathrm{Ca}>$ $\mathrm{Mg}>\mathrm{K}>\mathrm{N}>\mathrm{P}>\mathrm{S}$ for macronutrients, and $\mathrm{Fe}>\mathrm{Cu}>$ $\mathrm{Zn}>\mathrm{Mn}>\mathrm{B}$ for micronutrients [18]. Increasing rates of $\mathrm{Zn}$ to Jatropha curcas L. influenced Zn concentrations in the fourth leaf of the plant, sampled at 100 days after sowing (DAS) [19]. Similarly, increasing rate of $\mathrm{Cu}$ to Jatropha curcas L. increased $\mathrm{Cu}$ concentrations in the fourth leaf sampled 80, 100 and 120 DAS [20].

Increasing concentrations of micronutrients in irrigation water increased photosynthetic pigments, i.e. chlorophyll a, b, and carotenoids (Table 3). Accordingly, 150 ppm of Mn, Zn, and Fe treatment was most effective in promoting the synthesis and accumulation of photosynthetic pigments. Heithholt et al. [21] concluded that photosynthetic pigments in soybean were greater for all of the $\mathrm{FeSO}_{4}$ treatments, and that no negative response was evident at higher rates of $\mathrm{Fe}$ from $30-100 \mathrm{ppm}$. Effects of $\mathrm{Zn}$ ( 0 and $5.0 \mathrm{mg} \mathrm{Zn/kg}$ of soil) on photosynthetic rate $(\mathrm{PN})$, and chlorophyll fluorescence in maize leaves (cv. Zhongdan 9409) grown in different soil moisture regimes ( $40 \%-45 \%$ and $70 \%-75 \%$ of soil saturated water content) were investigated [22]. Zn application did not enhance maize plant adaptation to drought stress. The relative water content and the water potential of leaves were not affected by $\mathrm{Zn}$ treatment. The PN of drought-stressed plants was not improved by $\mathrm{Zn}$ supply. Plant biomass, stomatal conductance, and yields increased with $\mathrm{Zn}$ addition in well-watered plants. Kobraee et al. [23] concluded that supply of $\mathrm{Zn}$ (8 ppm), Mn, (30 ppm), and Fe (8 $\mathrm{ppm}$ ) with irrigation water to soybean increased pho- tosynthetic pigments which in turn have favorable response to yield and quality. These micronutrients are required in electronic transport reactions and are essential for the biosynthesis pathway of chlorophyll. Ghavri and Singh [24] demonstrated that adequate availability of $\mathrm{Fe}$ was essential for chlorophyll biosynthesis and function, energy transfer, and cell metabolism. Iron is a constituent of certain enzymes and proteins required for $\mathrm{N}$ fixation and plant respiration.

\section{Mineral Status}

Concentrations of all mineral elements in Jatropha plant leaves increased with increasing concentrations of $\mathrm{Mn}$, $\mathrm{Zn}$, and $\mathrm{Fe}$ up to $150 \mathrm{ppm}$ in irrigation water (Tables 4 and 5). The levels of mineral elements in the leaves decreased with further increase in concentration of micronutirents in the irrigation water. At the $150 \mathrm{ppm}$ level of $\mathrm{Fe}, \mathrm{Mn}$, and $\mathrm{Zn}$ treatment the leaf concentration of $\mathrm{N}$ was $143 \%$ greater than that for the plants which received no micronutrient supplement (Table 4). For the similar comparison the increase in concentration of other macronutrients was in the range of $21 \%$ to $42 \%$, while that of $\mathrm{Zn}$, $\mathrm{Mn}$, and Fe were $83 \%, 75 \%$, and $55 \%$, respectively. The increase in plant biomass weight and concentration of various mineral elements with increasing amounts of $\mathrm{Fe}$, $\mathrm{Mn}$, and $\mathrm{Zn}$ in irrigation water (up to $150 \mathrm{ppm}$ ) contributed to an increase in total uptake of mineral elements with increasing concentration of micronutrients in the irrigation water up to $150 \mathrm{ppm}$ (Figures 1 and 2). The increased concentrations of $\mathrm{Zn}, \mathrm{Mn}$ and $\mathrm{Fe}$ in the irrigation water appeared to influence ionic system which in turn affects the uptake, transport, photosynthesis and enzyme activities related to metabolism. The increased uptake of $\mathrm{Fe}, \mathrm{Mn}$, and $\mathrm{Zn}$ by Jatropha plants with increased availability of these micronutrients/heavy metals in the root environment appeared to suggest that Jatropha can be a suitable accumulator of heavy metals from soils, thus can be used for phytoremediation of heavy metals contaminated soils. Edaphic factors such as soil $\mathrm{pH}$, low organic matter, soil aeration, high soil phosphorus (P), forms of nitrogen $(\mathrm{N})$ applied, Fe:Zn balance, Fe:Mn 
Table 3. Influence of micronutrients (Mn, Zn, Fe) concentrations in irrigation water on photosynthetic pigments of Jatropha plant leaves, 75 days after emergence (DAE).

\begin{tabular}{ccccccc}
\hline $\begin{array}{c}\text { Concentrations } \\
\text { (ppm) }\end{array}$ & Chl_a & Chl_b & Chl_a + Chl_b & Carotinoids & Chl_a:Chl_b & Chl_a + Chl_b \\
\hline 0 & 3.99 & 1.67 & 5.66 & 2.79 & 2.39 & Carotinoids \\
50 & 4.87 & 1.96 & 6.83 & 3.74 & 2.48 & 1.31 \\
100 & 5.42 & 2.03 & 7.45 & 4.60 & 2.67 & 1.82 \\
150 & 6.24 & 2.47 & 8.71 & 6.09 & 2.97 & 1.43 \\
200 & 5.37 & 2.19 & 7.56 & 4.22 & 2.62 & 1.79 \\
250 & 4.63 & 2.05 & 6.68 & 4.22 & 2.27 & 1.58 \\
LSD (P $\leq 0.05)$ & 0.86 & 0.47 & 0.62 & 0.74 & 0.14 & 0.24 \\
\hline
\end{tabular}

LSD $=$ Least significant difference. The treatment differences in excess of the LSD for the respective parameter indicate significant differences. Chl_a = Chlorophyll a; Chl_b = Chlorophyll b.

Table 4. Influence of micronutrients ( $\mathrm{Mn}, \mathrm{Zn}, \mathrm{Fe}$ ) concentrations in irrigation water on concentrations of macronutrients in Jatropha plant leaves 75 days after emergence (DAE).

\begin{tabular}{ccccccc}
\hline $\begin{array}{c}\text { Mixture concentrations } \\
(\mathbf{p p m})\end{array}$ & $\mathbf{5}$ & $\mathbf{P}$ & $\mathbf{K}$ & $\mathbf{N a}$ & $\mathbf{C a}$ & $\mathbf{M g}$ \\
\cline { 2 - 7 } & 2.1 & 0.14 & 4.2 & 1.60 & 3.6 & 0.69 \\
0 & 2.9 & 0.18 & 4.7 & 1.68 & 3.9 & 0.73 \\
50 & 3.8 & 0.21 & 5.0 & 1.88 & 4.4 & 0.78 \\
100 & 5.1 & 0.25 & 5.1 & 2.08 & 5.1 & 0.87 \\
150 & 4.4 & 0.23 & 4.2 & 2.00 & 3.9 & 0.84 \\
200 & 3.5 & 0.23 & 4.2 & 1.63 & 3.7 & 0.72 \\
250 & 0.9 & 0.02 & 0.2 & 0.08 & 0.7 & 0.05 \\
\hline LSD (P $\leq 0.05)$ & & & & & & \\
\hline
\end{tabular}

LSD $=$ Least significant difference.

Table 5. Influence of micronutrients ( $\mathrm{Mn}, \mathrm{Zn}, \mathrm{Fe}$ ) concentrations in irrigation water on concentrations of $\mathrm{Zn}, \mathrm{Fe}$, and Mn in Jatropha plant leaves, 75 days after emergence (DAE).

\begin{tabular}{cccc}
\hline \multirow{2}{*}{$\begin{array}{c}\text { Concentrations } \\
(\mathbf{p p m})\end{array}$} & \multicolumn{3}{c}{$\mathbf{m g} / \mathbf{k g}$ on dry matter basis } \\
\cline { 2 - 4 } & $\mathbf{Z n}$ & $\mathbf{F e}$ & $\mathbf{M n}$ \\
\hline 0 & 64 & 89 & 60 \\
50 & 96 & 110 & 85 \\
100 & 105 & 152 & 105 \\
150 & 110 & 194 & 105 \\
200 & 88 & 184 & 100 \\
250 & 45 & 141 & 87 \\
LSD (P $\leq 0.05)$ & 6 & 11 & 8 \\
\hline
\end{tabular}

LSD $=$ Least significant difference. The treatment differences in excess of the LSD for the respective parameter indicate significant differences.

balance, $\mathrm{K}: \mathrm{Fe}$ balance, can affect the availability of $\mathrm{Fe}$ to the plants [24]. Different plant species develop adaptive mechanism to survive in soils with very high amounts of $\mathrm{Fe}$ and other metals. The results of this study indicate that Jatropha is suitable plant species for phytoremediation of Fe-contaminated soils. Kumar et al. [25] have

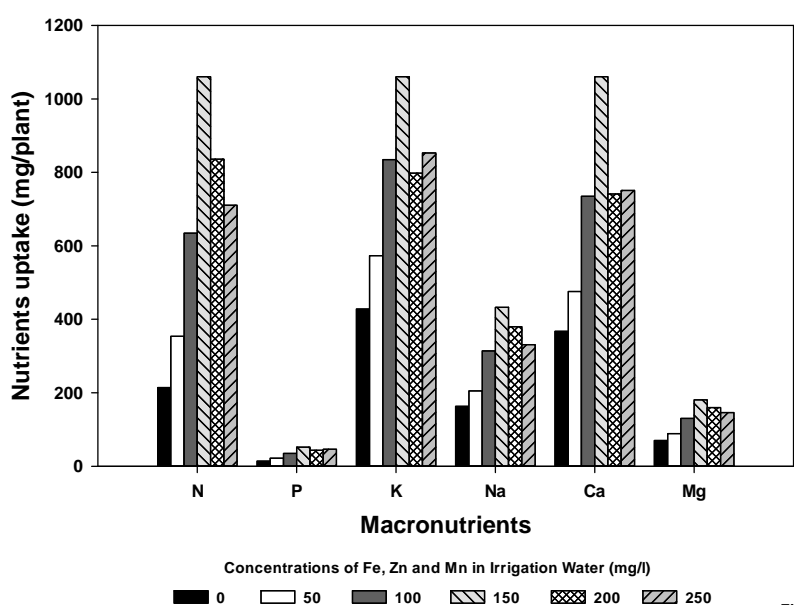

Figure 1. Effects of different concentrationsof Fe, Mn, and $\mathrm{Zn}$ in irrigation water on total amounts of macronutrients in Jatropha plants.

demonstrated beneficial effects of using dairy manure or biosolids amendments to enhance the growth of Jatropha plants in heavy metal contaminated soils. They also showed enhanced growth of Jatropha plants with Zn amendment. Although this pot experiment has indicated beneficial effects of increased concentrations of micronutrients in 


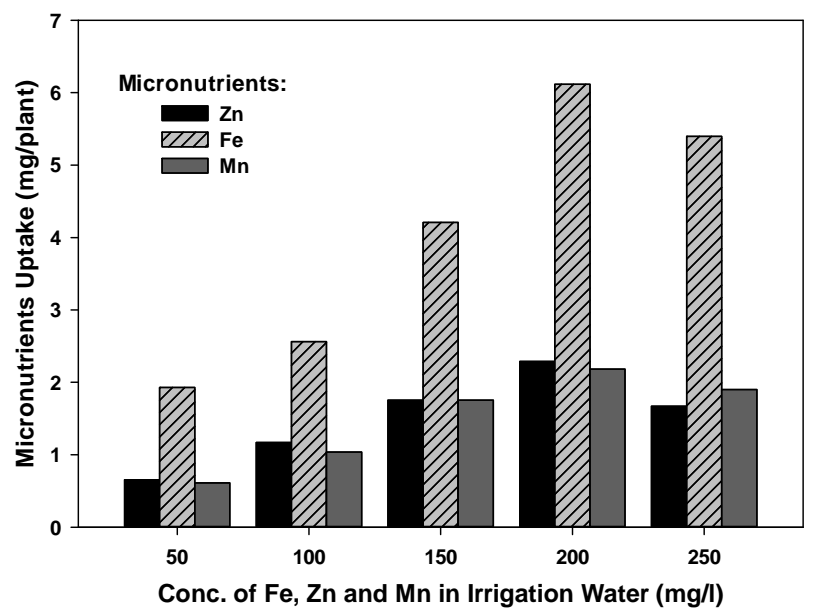

Figure 2. Effects of different concentrations of Fe, Mn, and $\mathrm{Zn}$ in irrigation water on total amounts of micronutrients in Jatropha plants.

irrigation water on Jatropha plants growth, photosynthetic pigments, and nutrients uptake, further long-term field experiments are needed to confirm these beneficial responses.

\section{Conclusion}

This study has demonstrated beneficial responses of Jatropha plants to increased concentrations of $\mathrm{Mn}, \mathrm{Zn}$, and $\mathrm{Fe}$ in irrigation water up to $150 \mathrm{ppm}$. No favorable response was evident with further increase in micronutrients concentrations. However further studies are recommended to evaluate the role of micronutrients application to soil vs. foliar on the growth and photosynthetic pigment response of Jatropha in long term field studies under varied soil and climate conditions. With potential increase in production of Jatropha as a biofuel feedstock in the future, developing optimal nutrient management, including micronutrients management, will become a priority to manage this new crop in difficult production regions and utilize resources, which are unsuitable for production of food and feed crops.

\section{REFERENCES}

[1] A. Ghafoor, A. Rauf, M. Arif and W. Muzzafar, "Chemical Composition of Effluent from Different Industries from Faisalabad City," Pakistan Journal of Agricultural Science, Vol. 31, 1995, pp. 37-69.

[2] G. R. Rout and P. Das, "Effect of Metal Toxicity on Plant Growth and Metabolism: I. Zinc," Agronomy, Vol. 23, 2003, pp. 3-11.

[3] M. R. Broadley, P. J. White, J. P. Hammond, I. Zelko, and A. Lux, "Zinc in Plant," New Phytologist, Vol. 173, 2007, pp. 677-702. doi:10.1111/j.1469-8137.2007.01996.x

[4] G. Abbas, M. Q. Khan, M. Jamil, M. Tahir and F. Hus- sain. Nutrient Uptake, Growth and Yield of Wheat (Triticumaestivum) as Affected by Zinc Application Rates," International Journal of Agriculture \& Biology, Vol.11, No. 4, 2009, pp. 389-396.

[5] M. Debnath and P. S. Bisen, "Jatropha curcas L.: A Multipurpose Stress Resistant Plant with a Potential for Ethno Medicine and Renewable Energy," Current Pharmaceutical Biotechnology, Vol. 9, No. 4, 2008, pp. 288-306. doi: $10.2174 / 138920108785161541$

[6] H. A. Abdelgadir, S. D. Johnson and J. V. Staden, "Promoting Branching of a Potential Biofuel Crop Jatropha curcas L. by Foliar Application of Plant Growth Regulators," Plant Growth Regulation, Vol.58, No. 3, 2007, pp. 287-295. doi:10.1007/s10725-009-9377-9

[7] S. K.Behera, P. Srivastava, R. Tripathy, J. P. Singh and N. Singh, "Evaluation of Plant Performance of Jatropha curcas L. under Diferent Agro-Practices for Optimizing Biomass: A Case Study," Biomass and Bioenergy, Vol. 34, 2010, pp. 30-41. doi:10.1016/j.biombioe.2009.09.008

[8] A. A. A.Kheira and N. M. M. Atta, "Response of Jatropha curcas L. to Water Deficits: Yield, Water Use Efficiency and Oil Seed Characteristics," Biomass and Bioenergy, Vol. 33, 2009, pp. 1343-1350.

[9] G. R. Rao, G. R. Korwar, A. K. Shanker and Y. S. Ramakrishna, "Genetic Associations, Variability and Diversity in Seed Characters, Growth, Reproductive Phonology and Yield in Jatropha curcas L. Accessions," Trees, Vol. 22, No. 5, 2008, pp. 697-709. doi:10.1007/s00468-008-0229-4

[10] L. Ruth, "Bio or Bust? The Economic and Ecological Cost of Biofuels," EMBO-Reports, Vol. 9, 2008, pp. 130133. doi:10.1038/sj.embor.2008.6

[11] S. Gao, R. Yan, M. Cao, W. Yang, S. Wang and F. Chen, "Effects of Copper on Growth, Antioxidant Enzymes and Phenylalanine Ammonialyase Activities in Jatropha curcas L. Seedling," Plant Soil Environment, Vol. 54, No. 3, 2008, pp. 117-122.

[12] S. Gao, Q. Li, C. Ou-Yang, L. Chen, S. Wang and F. Chen, "Lead Toxicity Induced Antioxidant Enzyme and Phenylalanine Ammonialyase Activities in Jatropha curcas L. Radicles," Fresenius Environmental Bulletin, Vol. 18, No. 5b, 2009, pp. 811-815.

[13] H. K. Elminir, F. F. Areed and T. S. Elsayed, "Estimation of Solar Radiation Components Incident on Helwan Site Using Neural Networks," Solar Energy, Vol. 79, No. 3, 2005, pp. 270-279. doi:10.1016/j.solener.2004.11.006

[14] A. Cottenie, M. Verloo, L. Kiekens, G. Velghe and R. Camerlynck, "Chemical Analysis of Plant and Soil Laboratory of Analytical and Agrochemistry," State University Ghent, Belgium, 1982, pp. 100-129.

[15] M. Saric, R. Kostrori, T. Cupina and I. Geric, "Chlorophyll Determination," Univ. Noven Sadu Prakitikum is kiziologize Bilijaka Beogard, Haucana, Anjiga, 1967.

[16] G. W. Snedecor and W. G. Cochran, "Statistical Methods," 7th Edition, Iowa State University Press, Iowa, 1980.

[17] L. H. G. Chaves,T. H. C. Cunha, G. Barros, R. D. Lacerda and E. E. de Dantas, "Zinc and Copper in Jatropha 
curcas. L. Initial Growth of Culture," Journal Caatinga, Vol. 22, No. 3, 2009, pp. 94-99.

[18] E. B. Silva, L. P. P. Tanure, S. R. Santos and P. S. Resende, "Visual Symptoms of Nutrient Deficiency in Physic Nut," Pesquisa Agropecuária Brasileira, Vol. 44, No. 4, 2009, pp. 392-397. doi:10.1590/S0100-204X2009000400009

[19] L. H. G. Chaves, P. C. Cabral, G. Barro, R. D. Lacerda and E. E. Dantas, "Zinc and Copper in Jatropha curcas L. Elements Concentration in Leaves and Stems," Journal Caatinga, Vol. 22 No. 3, 2009, pp. 100-106.

[20] B. G. Laviolaand and L. A. Dias, "Nutrient Concentration in Jatropha curcas L. Leaves and Fruits and Estimated Extraction at Harvest," Revista Brasileira de Ciência do Solo, Vol. 32, No. 5, 2008, pp. 1969-1975.

[21] J. J. Heitholt, J. J. Sloan, C. T. Mackown, and R. I. Cabreva, "Soybean Growth on Calcareous Soil as Affected by Three Iron Sources," Journalof Plant Nutrition, Vol. 25, No. 8, 2003, pp. 1727-1740.

doi:10.1081/PLN-120006054
[22] H. Wang, R. L. Liu and J. Y. Jin, "Effect of Zinc and Soil Moisture on Photosynthetic Rate and Chlorophyll Fluorescence's Parameters of Maize Plants," Biologia Plantarum, Vol. 53, No. 1, 2009, pp. 191-194. doi:10.1007/s10535-009-0033-Z

[23] S. Kobraee, K. Shamsi and S. Eklitiori, "Soybean Nodulation, Chlorophyll Concentration Affected by Some Micronutrients," Annals of Biological Research, Vol. 2, No. 2, 2011, pp. 414-422.

[24] Ghavri and P. Singh, "Phytotranslocation of Fe by Biodiesel Plant Jatropha curcas L. Grown on Iron Rich Wasteland Soil," Brazilian Journal of Plant Physiology, Vol. 22, No. 4, 2010, pp. 235-243. doi:10.1590/S1677-04202010000400003

[25] G. P. Kumar, S. K. Yadav, P. R. Thawale, S. K. Singh and A. A. Juwarkar, "Growth of Jatropha curcas on Heavy Metal Contaminated Soil Amended with Industrial Wastes and Azotobacter-A Greenhouse Study," Bioresource Technology, Vol. 99, No. 6, 2008, pp. 2078-2082. doi:10.1016/j.biortech.2007.03.032 